\title{
Toward the Biochemical Assessment of Myocardial Fibrosis in Hypertensive Patients
}

\author{
Javier Díez, MD, PhD, Concepción Laviades, MD, PhD, Ignacio Monreal, DSc, MD, \\ María J. Gil, DSc, Angel Panizo, MD, and Javier Pardo, MD, PhD
}

The serum concentrations of amino-terminal procollagen type III and carboxy-terminal procollagen type l-derived peptides, which have been proposed as useful markers of the tissue synthesis of collagen types III and type I, respectively, were abnormally increased in patients with essential hypertension and became normal after angiotensin-converting enzyme (ACE) inhibition. An association was found between baseline serum concentrations of these peptides and left ventricular hypentrophy, diastolic dysfunction, and ventricular arrhythmias in hypertensive patients. On the other hand, increased se- rum concentration of the carboxy-terminal procollagen type 1-derived peptide was found in spontaneously hypertensive rats compared with normotensive Wistar-Kyoto control rats. An association was found between the serum concentration of this peptide and the extent of myocardial fibrosis and the hydroxyproline concentration in the left ventricle of spontaneously hypertensive rats. It is proposed that procollagen-derived peptides in serum may be markers of exaggerated collagen tissue synthesis involved in hypertensive myocardial fibrosis.

(Am J Cardiol 1995; 76:14D-17D)
A significant increase in fibrillar collagen content has been observed in the cardiac ventricles of both animals ${ }^{1-7}$ and humans ${ }^{8-12}$ with arterial hypertension. This myocardial fibrosis is accomplished by altcrations in collagen synthesis and degradation and by fibroblast proliferation. ${ }^{13,14}$ Hemodynamic and nonhemodyanmic factors may participate in the development of myocardial fibrosis that occurs in hypertension. ${ }^{15,16}$ As shown experimentally,17 and clinically, ${ }^{18}$ a rise in collagen content adversely raises myocardial stiffness and promotes abnormalities of cardiac function. In addition, it has been demonstrated that ventricular arrhythmias in hypertensive patients are related to the degree of myocardial fibrosis. ${ }^{19}$ Although some antihypertensive agents, such as minoxidil, hydralazine, or hydrochlorothiazide, have failed to show any significant effect on myocardial fibrosis, others, such as angiotensin-converting enzyme (ACE) inhibitors, calcium antagonists, or aldosterone antagonists, have demonstrated profound effects on either prevention or regression of myocardial fibrosis. ${ }^{20}$

Although cardiac biopsies are reliable for measuring myocardial fibrosis, ${ }^{10,11,18,21}$ it seems neces-

\footnotetext{
From the Vascular Pathophysiology Unit, Department of Internal Medicine, Center for Biomedical Research, School of Medicine, University of Navarra (J.D.); Division of Nephrology, San Jorge General Hospital, Huesca (C.L.); Department of Clinical Biochemistry, University Clinic, School of Medicine, University of Navarra (I.M., M.J.G.); and Department of Pathology, University Clinic, School of Medicine, University of Navarra, Pamplona, Spain (A.P., J.P.).

Address for reprints: Javier Díez, MD, PhD, Unidad de Fisiopatología Vascular, Facultad de Medicina, C/ Irunlarrea s/n, 31080 Pamplona, Spain.
}

sary to develop noninvasive methods that indicate the presence of myocardial fibrosis in hypertension (i.c., biochemical markers of collagen synthesis). This article is based on the proposal of a biochemical method to assess indirectly the myocardial synthesis and deposition of fibrillar collagen.

\section{A BIOCHEMICAL APPROACH TO THE ASSESSMENT OF THE CARDIAC SYNTHESIS OF FIBRILLAR COLLAGEN}

Collagen types III and I are synthesized as procollagens with a small amino-terminal and a larger carboxy-terminal propeptide. Once secreted into the extracellular space, the propeptides are removed by specific endopeptidases, thus allowing integration of the rigid collagen triple helix into the growing fibril. ${ }^{22}$ The procollagen type III aminoterminal peptide (PIIIP) formed during this process is released into the blood. The serum concentration of PIIIP has been proposed as a useful marker of collagen type III synthesis. ${ }^{23}$ This is supported by a diversity of clinical observations demonstrating that high serum levels of the peptides reflect ongoing tissue fibrosis. ${ }^{24-28}$

The procollagen type I carboxy-terminal peptide (PIP) is cleaved off procollagen type I during the synthesis of the fibril forming collagen type I. In contrast to PIIIP, PIP is completely removed from its procollagen precursor during the extracellular processing of the collagen type $1,{ }^{22}$ thus offering the theoretical advantage of directly reflecting fibrogenesis. This has been confirmed in studies conducted in patients with different clinical conditions. ${ }^{29-31}$ 
Therefore, we investigated the serum concentrations of PIP and PIIIP in different clinical and experimental studies to assess the intensity of the fibrogenic process in patients with essential hypertension and in rats with spontaneous hypertension. In addition, the relations between serum concentrations of the 2 peptides and several parameters of left ventricular anatomy, structure, biochemistry, and function were analyzed to delineate the value of these peptides as potential markers of ventricular fibrosis in hypertension.

\section{STUDIES ON SERUM PEPTIDES OF COLLAGEN SYNTHESIS IN ARTERIAL HYPERTENSION}

Clinical studies: In a previous study ${ }^{32}$ we determined, by specific radioimmunoassay, the serum concentrations of PIIIP in 24 patients with essential hypertension who had never been treated and in 30 normotensive control subjects. None of the subjects exhibited abnormalities suggestive of conditions associated with elevated serum PIIIP concentrations (chronic liver disease, pulmonary fibrosis, rheumatoid arthritis, extensive wounds, acute myocardial infarction).

As shown in Figure 1, serum PIIIP was higher in hypertensive patients than in control subjects $(11.20 \pm 0.76$ vs $8.47 \pm 0.77 \mathrm{ng} / \mathrm{ml}$, mean $\pm \mathrm{SEM}$; $\mathrm{p}<0.01)$. A direct correlation was found between serum PIIIP and plasma renin activity in the group of hypertensive patients. In addition, serum PIIIP was correlated inversely with maximal early transmitral flow velocity measured during diastole by Doppler echocardiography in the group of hypertensive patients.

Serum concentrations of PIIIP were measured in 15 patients after receiving the ACE inhibitor lisinopril (10-20 mg once daily) for 6 months. The serum PIIIP concentrations decreased significantly in these patients $(11.76 \pm 0.84$ vs $8.47 \pm 0.66 \mathrm{ng} /$ $\mathrm{ml} ; \mathrm{p}<0.01$; Figure 1). Blood pressure became normal after treatment with lisinopril. Echocardiographic parameters assessing left ventricular mass were diminished after the treatment period. Trends toward normalization of diastolic filling parameters after treatment did not attain statistical significance.

In another study we measured serum PIP in 50 patients with essential hypertension who had never been treated and in 30 normotensive control subjects. ${ }^{33}$ Serum PIP was measured by specific radioimmunoassay. Conditions associated with elevated serum concentrations of PIP (alcoholic liver disease, metabolic bone disease) were excluded after a complete medical examination. Measurements were repeated in 43 hypertensive patients after 6 months of treatment with lisinopril (10-20 mg once daily).

Baseline serum concentrations of PIP were increased in hypertensive patients compared with normotensive subjects $(139 \pm 6$ vs $108 \pm 6 \mu \mathrm{g} / \mathrm{L}$; $\mathrm{p}<0.001$; Figure 2). Serum PIP was correlated directly with the left ventricular mass index in the group of hypertensive patients. In addition, serum PIP concentrations increased in parallel with the increase in the Lown-Wolf grade of ventricular arrhythmias in the group of hypertensive patients.

In treated patients blood pressure became normal and there was a regression of left ventricular mass index and a diminution in the number of daily ventricular extrasystoles. Serum PIP concentrations decreased to normal values in patients treated with lisinopril $(111 \pm 5$ vs $108 \pm 6 \mu \mathrm{g} / \mathrm{L} ; \mathrm{p}<0.001$; Figure 2).

Experimental study: In a pilot study, we evaluated serum PIP concentrations in 736-week-old male spontaneously hypertensive rats with established left ventricular hypertrophy. Specific radioimmunoassay was used to measure serum PIP in rats. The amount of left ventricular collagen was evaluated by measuring the hydroxyproline concentration. The collagen-specific stain, Masson's trichrome, was used to evaluate the presence and intensity of interstitial and perivascular fibrosis of the left ventricle.

In spontaneously hypertensive rats compared with 7 age- and sex-matched Wistar-Kyoto normotensive control rats we found: (1) an increase in hydroxyproline concentration $(1.05 \pm 0.03$ vs $0.84 \pm 0.05 \mu \mathrm{M} / \mathrm{g}$ dry weight $/ 100 \mathrm{~g}$ body weight; $\mathrm{p}<0.05$; Figure 3 ); and (2) an increase in serum PIP $(10.31 \pm 0.58$ vs $8.25 \pm 0.59 \mu \mathrm{g} / \mathrm{L}, \mathrm{p}<0.05$; Figure 4).

All the spontaneously hypertensive rats exhibited severe interstitial and perivascular fibrosis. The absence of pathologic myocardial fibrosis was seen in 6 normotensive rats. One Wistar-Kyoto rat exhibited mild interstitial fibrosis.

\section{COMMENTS}

The findings of the studies show an increase in serum concentrations of PIIIP and PIP in patients with essential hypertension and in spontaneously hypertensive rats. Elevated serum PIIIP and PIP may be markers of increased collagen type III and type I synthesis in arterial hypertension.

The question arises as to whether the measurement of PIIIP and PIP accurately reflects tissue 
fibrillogenesis. In this regard, in experiments of quantification of fibroproliferative reactions in situ, it has been shown that the PIIIP and the PIP assays reflect ongoing collagen synthesis. In fact, when the expression of procollagen type III and procollagen type $I$ is induced, as during wound healing and other repair processes, ${ }^{34,35}$ the local concentrations of the PIIIP and the PIP antigens in interstitial fluid increase dramatically, This is in agreement with a number of clinical observations showing that the circulating levels of the 2 peptides correlate well with ongoing tissue fibrosis. ${ }^{24-31}$

We are aware that by measuring serum procollagen-derived peptides we assess the formation of

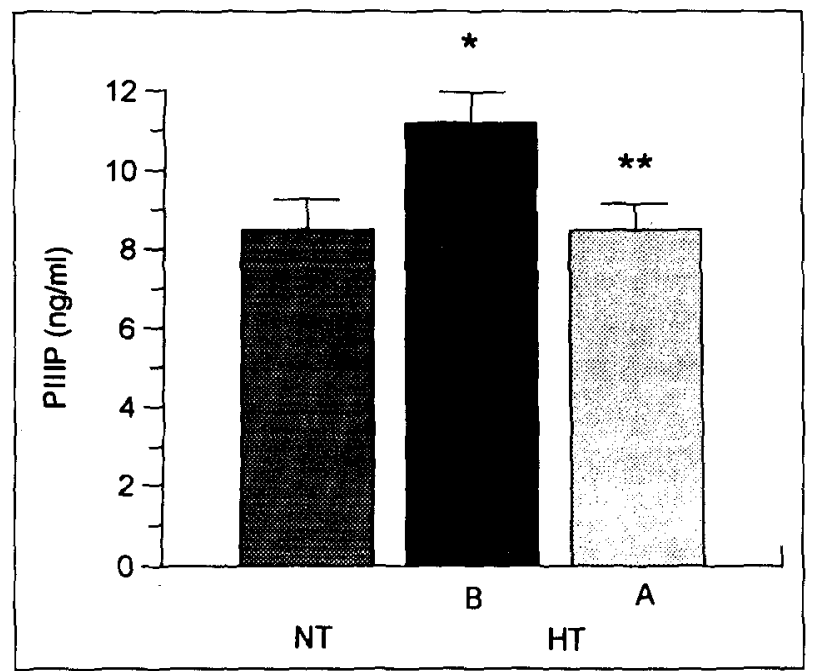

FIGURE 1. Serum concentrations of procollagen type III amino-terminal peptide (PIIIP) in normotensives (NT) and essential hypertensives ( $\mathrm{HT}$ ) before (B) and ofter (A) treatment. ${ }^{*} p<0.01$ compored with $N T ;{ }^{* *} p<0.01$ compared with $\mathrm{HT}$ before treatment.

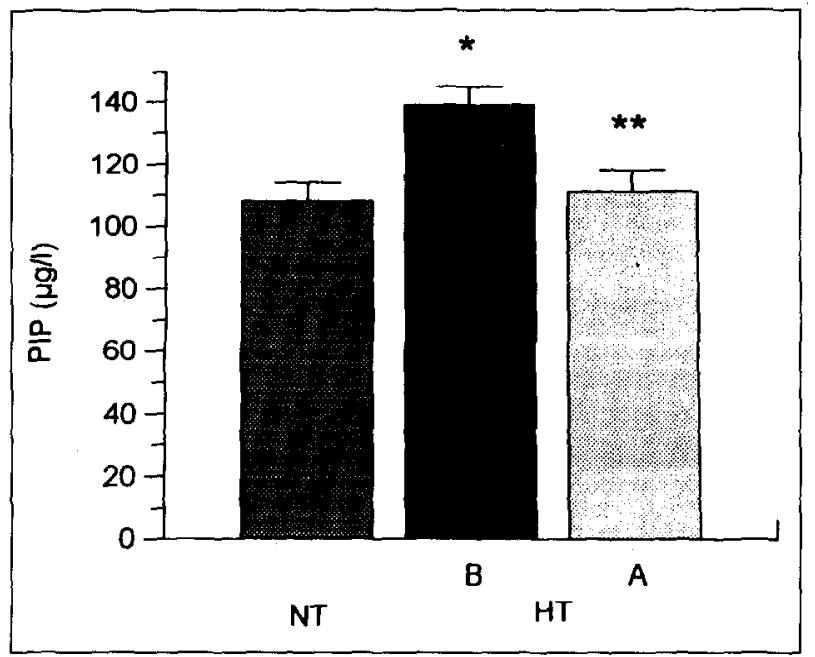

FIGURE 2. Serum concentrations of procollagen type I carboxy-ferminal peptide (PIP) in normotensives (NT) and essential hypertensives (HT) before (B) and after (A) treatment. ${ }^{*} p<0.001$ compared with NT; ${ }^{* *} p<0.001$ compared with HT before treatment. fibrillar collagen but not its degradation. Since collagen degradation is also altered in arterial hypertension, ${ }^{13}$ additional studies are necessary to assess in a more complete way collagen metabolism in hypertension.

The effects of lisinopril on the serum concentrations of the 2 peptides in hypertensive patients suggest that the renin-angiotensin-aldosterone system may participate in the excessive synthesis of collagen types III and I in essential hypertension. This is in agreement with the observation that in spontaneously hypertensive rats with left ventricular hypertrophy and fibrosis of the cardiac interstitium, lisinopril reversed fibrous tissue accumulation. ${ }^{36}$

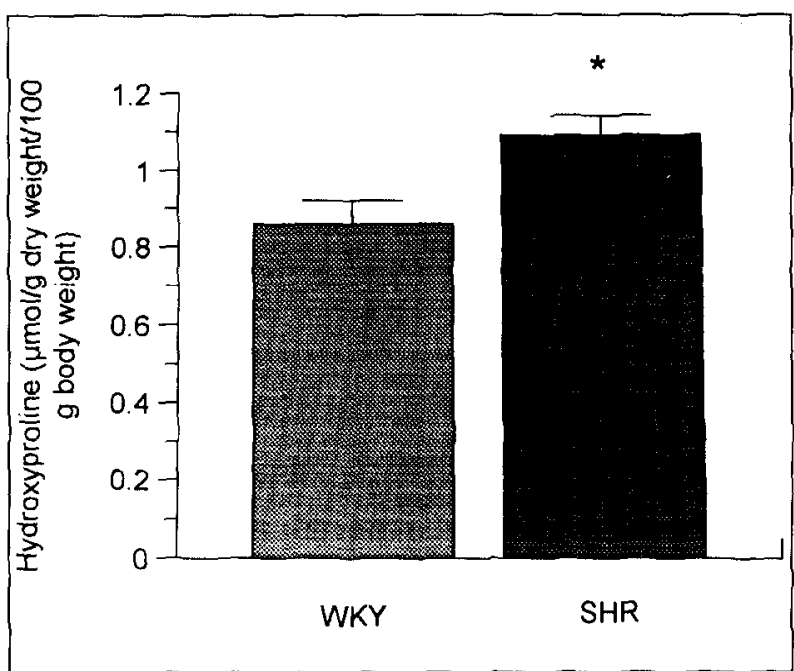

FIGURE 3. Hydroxyproline concentration in normotensive Wistar-Kyoto rats (WKY) and spontaneously hypertensive rats (SHR). ${ }^{*} p$ < 0.05 compared with WKY.

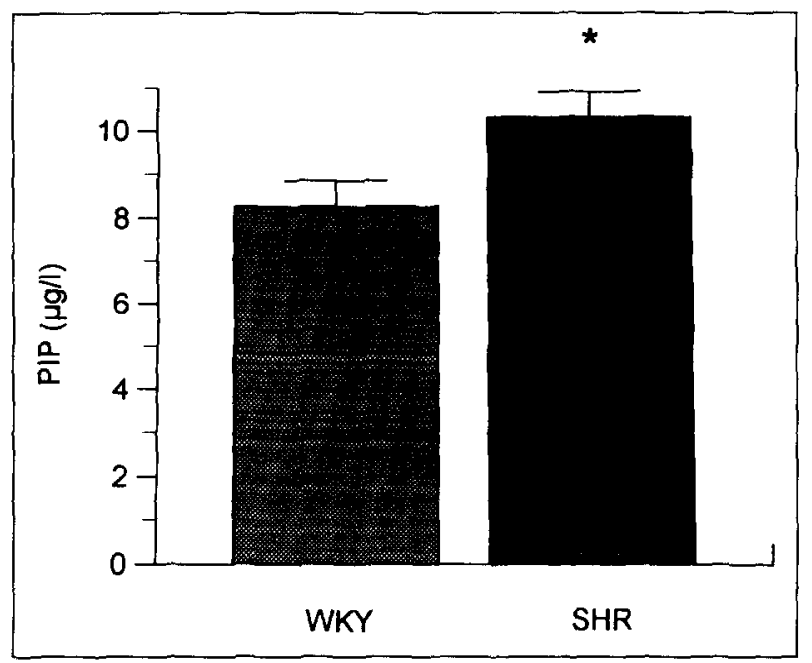

FIGURE 4. Serum concentrations of procollagen type I carboxy-terminal peptide (PIP) in normotensive Wistar-Kyoto rats (WKY) and spontaneously hypertensive rats (SHR). *p $<0.05$ compared with WKY. 
The relations observed between serum PIIIP and PIP and parameters of mass, function, and electrical activity of the left ventricle suggest that circulating procollagen-derived peptides may reflect ongoing myocardial fibrosis in essential hypertension. However, because no cardiac biopsies were performed in the clinical studies mentioned here, the cardiac origin of the 2 peptides remains speculative, and other extracardiac sources deserve to be considered.

In this regard, our finding that serum PIP is increased in spontaneously hypertensive rats with fibrosis of the left ventricle due to an excess of collagen deposition serves to reinforce the role of this peptide as a potential serum marker of myocardial collagen type I synthesis in hypertension.

In summary, the findings presented here permit us to propose that serum procollagen peptide measurements may provide indirect diagnostic information on the myocardial fibrosis associated with arterial hypertension. Histopathologic studies of the left ventricle of patients with arterial hypertension should be carried out to confirm or reject this hypothesis.

1. Doering CW, Jalil JE, Janicki JS, Pick R, Aghili S, Abrahams C, Weber KT. Collagen network remodeling and diastolic stiffness of the rat left ventricle with pressure overload hypertrophy. Cardiovasc Res 1988;22:686-695.

2. Michel JB, Salzmann JL, Carol ML, Dussaule JC, Azizi M, Corman B, Camilleri JP, Corvol P. Myocardial effect of converting enzyme inhibition in hypertensive and normotensive rats. Am J Med 1988;84(suppl 3):A12-A21.

3. Jalil JE, Doering CW, Janicki JS, Pick R, Clark WA, Weber KT. Fibrillar collagen and myocardial stiffness in the intact hypertrophied rat left ventricle. Cinc Res 1989;64:1041-1050.

4. Pfeffer JM, Pfeffer MA, Fishbein MC, Frohlich ED. Cardiac function and morphology with aging in the spontaneously hypertensive rat. Am $J$ Physid 1979;6(suppl):H461-H468.

5. Pick R, Janicki JS, Weber KT. Myocardial fibrosis in nonhuman primate with pressure overload hypertrophy. Am J Pathol 1989;135:771-781.

6. Weber KT, Janicki JS, Pick R, Abrahams C, Shroff SG, Bashey RI, Chen RM. Collagen in the hypertrophied pressure-overloaded myocardium. Circulation 1987;75:40-47.

7. Abrahams C, Janicki JS, Weber KT. Myocardial hypertrophy in Macaca fascicularis: structural remodeling of the collagen matrix. Lab Invest 1987;56:676683.

8. Caspari PG, Newcomb M, Gibson K, Harris P. Collagen in the normal and hypertrophied human ventricle. Cardiovasc Res 1977;11:554-558.

9. Anderson KR, St John Sutton MG, Lie JT. Histopathological types of cardiac fibrosis in myocardial disease. $J$ Pathol 1979;128:79-85.

10. Pearlman ES, Weber KT, Janicki JS, Pietra G, Fishman AP. Muscle fiber orientation and connective tissue content in the hypertrophied human heart. Lab Invest 1982;46:158-164.

11. Huysman JAN, Vlicgen HW, Vanderlaarse A, Eulderink F. Changes in nonmyocyte tissue composition associated with pressure overload of hypertrophied human hearts. Pathol Res Pract 1989;184:577-581.

12. Pardo-Mindan FJ, Panizo A. Alterations in the extracellular matrix of the myocardium in essential hypertension. Eur Hear $J$ 1993;14(suppl J):12-14.

13. Weber KT, Eghbali M. Collagen matrix synthesis and degradation in the development and regression of left ventricular hypertrophy. Cardiovasc Rev Rep 1991;12:61-69.

14. Eghbali M, Blumenfeld OO, Seifter S, Buttrick PM, Leinwand LA, Robin- son TF, Zern MA, Giambrone MA. Localization of types I, III, and IV collagen mRNAs in rat heart cells by in situ hybridization. $J$ Mol Cell Cardiol 1989;21:103-113.

15. Weber KT, Sun Y, Guarda E. Structural remodeling in hypertensive heart disease and the role of hormones. Hypertension 1994;23(part 2):869-877.

16. Fujita M, Mikunija A, McUown DP, Franklin D. Regional myocardial volume alterations induced by brief repeated coronary occlusion in conscious dogs. J Am Coll Cardiol 1988;12:1048-1053.

17. Thiedemann KU, Holubarsch C, Medugorac I, Jacob R. Connective tissue content and myocardial stiffness in pressure overload hypertrophy: a combined study of morphologic, morphometric, biochemical and mechanical parameters. Basic Res Cardiol 1983;78:140-155.

18. Hess OM, Schneider J, Kock R, Bamert C, Grimm J, Krayenbuehl HP. Diastolic function and myocardial structure in patients with myocardial hypertrophy. Cinculation 1981;63:360-371.

19. McLenachan JM, Dargie HJ. Ventricular arrhythmias in hypertensive left ventricular hypertrophy. Relationship to coronary artery disease, left ventricular dysfunction, and myocardial fibrosis. Am J Hypentens 1990;3:735-740.

20. Brilla CG, Weber KT. Pharmacological modulation of abnormal myocardial growth in hypertensive heart disease. In: Diez J, Dzau VJ, Ferrari R, Frohlich ED, eds. Molecular Cell Biology of Cardiowascular Diseases. Madrid: Musby-Duyma, 1995:334-344

21. Villari B, Campbell SE, Hess OM, Mall G, Vassalli G, Weber KT, Krayenbuehl HP. Influence of collagen network on left ventricular systolic and diastolic function in aortic valve disease. $J$ Am Coll Cardiol 1993;22:1477-1484.

22. Nimni ME. Fibrillar collagens: their byosynthesis, molecular structure, and mode of assembly. In: Zern MA Reid LM, eds. Extracellular Matrix. New York: Marcel Dekker, 1993:121-148.

23. Risteli L, Risteli J, Noninvasive methods for detection of organ fibrosis. In: Rojkind M, ed. Focus on Connective Tissue in Health and Disease. Boce Raton, FL: CRC Press, 1990:61-98.

24. Trinchet JC, Hartmann DJ, Pateron D, Laarif $M$, Callard $P$, Ville $G$, Beaugrand $M$. Serum type I collagen and N-terminal peptide of type III procollagen in chronic hepatitis. Relationship to liver histology and conventional liver tests. J Hepatol 1991;12:139-144.

25. Low RB, Cutroneo KR, Davis GS, Giancola MS. Lavage type III procollagen N-terminal peptides in human pulmonary fibrosis and sarcoidosis. Lab Invest 1983;48:755-759.

26. Horslev-Petersen $K$, Bentsen $K$, Junker P, Lorenzen I. Serum aminoterminal type III procollagen peptide in rheumatoid arthritis. Arthritis Rheum 1986;29: 592599.

27. Bentsen KD, Lanng C, Horslev-Petersen $K$, Risteli J. The aminoterminal propeptide of type III procollagen and basement membrane components in serum during wound healing in man. Acta Chir Scand 1988;154:97-101.

28. Thorbjorn Jensen L, Horslev-Petersen $K$, Toft $\mathbf{P}$, Bentsen $K D$, Grande $P$, Simonsen EE, Lorenzen I. Serum aminoterminal type III procollagen peptide reflects repair after acute myocardial infarction. Circulation 1990;81:52-57.

29. Schuppan D. Connective tissue polypeptides in serum as parameters to monitor antifibrotic treatment in hepatic fibrogenesis. $J$ Hepatol 1991;13(suppl 3):S17-\$25.

30. Savolainen ER, Goldberg B, Leo MA, Velez M, Lieber CS. Diagnostic value of serum procollagen peptide measurements in alcoholic liver disease. Alcoholism Clin Exp Res 1984;8:384-389.

31. Parfitt AM, Simon LS, Villanueva AR, Krane SM. Procollagen type I carboxy-terminal extension peptide in serum as marker of collagen biosynthesis in bone. Correlation with iliac bone formation rates and comparison with total alkaline phosphatase. J Bone Miner Res 1987;2:427-436.

32. Laviades C, Mayor G, Diez J. Treatment with lisinopril normalizes serum concentrations of procollagen type III amino-terminal peptide in patients with essential hypertension. Am J Hypertens 1994:7:52-58.

33. Díez J, Laviades C, Mayor G, Gil MJ, Monreal I. Increased serum concentrations of procollagen peptides in essential hypertension. Relation to cardiac alterations. Cinculation 1995;91:1450-1456.

34. Haukiporo K, Risteli L, Kairaluoma MI, Risteli J. Aminoterminal propeptide of type III procollagen in healing wounds in humans. Ann Surg 1987;206:752756.

35. Haukiporo K, Melkko J, Risteli L, Kairaluoma MI, Risteli J. Synthesis of type I collagen in healing wounds in humans. Ann Surg 1991;213:75-80.

36. Brilla CG, Janicki JS, Weber KT. Cardioreparative effects of lisinopril in rats with genetic hypertension and left ventricular hypertrophy. Circulation 1991;83:1771-1779. 